\title{
FORMAL AXIOLOGY AND ITS CRITICS
}




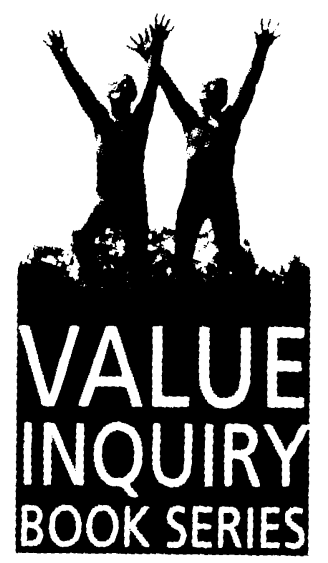

\title{
VIBS
}

Volume 33

\author{
Robert Ginsberg \\ Executive Editor
}

John M. Abbarno

Associate Editors

Virginia Black

H. G. Callaway

Rem B. Edwards

Heta Häyry

Matti Häyry

Richard T. Hull

Roberta Kevelson

Joseph C. Kunkel

Sander H. Lee

Ruth M. Lucier

Thomas Magnell

Alan Milchman

George David Miller

Michael H. Mitias

Myra Moss

Samuel M. Natale

Alan Rosenberg

Daniel Statman

a volume in

Hartman Institute Axiology Studies

HIAS

Rem B. Edwards, Editor 


\section{FORMAL AXIOLOGY AND ITS CRITICS}

Edited by

Rem B. Edwards

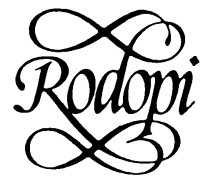

Amsterdam - Atlanta, GA 1995 
This is an open access title distributed under the terms of the CC BYNC-ND 4.0 license, which permits any non-commercial use, distribution, and reproduction in any medium, provided no alterations are made and the original author(s) and source are credited. Further information and the complete license text can be found at https://creativecommons.org/ licenses/by-nc-nd/4.0/

The terms of the CC license apply only to the original material. The use of material from other sources (indicated by a reference) such as diagrams, illustrations, photos and text samples may require further permission from the respective copyright holder.

\section{DOBERT S. HARTMAN $\overline{000} \mid$ INSTITUTE}

Open Access funding for this volume has been provided by the Robert S. Hartman Institute.

Cover design by Chris Kok based on a photograph, (C) 1984 by Robert Ginsberg, of statuary by Gustav Vigeland in the Frogner Park, Oslo, Norway.

(@) The paper on which this book is printed meets the requirements of "ISO 9706:1994, Information and documentation - Paper for documents Requirements for permanence".

ISSN: 0929-8436

ISBN (hardback): 978-90-5183-910-4

ISBN (paperback): 978-90-5183-897-8

E-ISBN: 978-90-04-49596-8

Copyright 2021 by the authors and editor. Published by Koninklijke Brill NV, Leiden, The Netherlands.

Koninklijke Brill NV incorporates the imprints Brill, Brill Nijhoff, Brill Hotei, Brill Schöningh, Brill Fink, Brill mentis, Vandenhoeck \& Ruprecht, Böhlau Verlag and V\&R Unipress. 
For our unique granddaughter:

Sara Louise Saad 
Rem B. Edwards - 9789004495968

Downloaded from Brill.com04/26/2023 09:48:54AM via free access 


\section{CONTENTS}

Editorial Foreword $\ldots \ldots \ldots \ldots \ldots \ldots \ldots \ldots \ldots$ REM B. EDWARDS

Acknowledgments $\ldots \ldots \ldots \ldots \ldots \ldots \ldots \ldots \ldots$ xiii

Chapters:

ONE Introduction $\ldots \ldots \ldots \ldots \ldots \ldots \ldots \ldots$

REM B. EDWARDS

Endnotes $\ldots \ldots \ldots \ldots \ldots \ldots \ldots \ldots \ldots$

PART ONE: EARLIEST CRITICS

TWO Axiology as a Science: Reply to Hector Neri Castañeda, 196111 ROBERT S. HARTMAN

1. The Argument of the Book . . . . . . . . . . . 12

2. Logical Positivism and Axiological Positivism . . . . . 15

3. Ethics and Meta-Ethics ... . . . . . . . . . . . . 19

4. Physics and Ethics-Metaphysics and Metaethics . . . . . 23

5. Science and Philosophy as Methods . . . . . . . . . 24

6. The Fallacy of Method . . . . . . . . . . . . . 27

7. The Logical Difference Between Valuation and Description .. 30

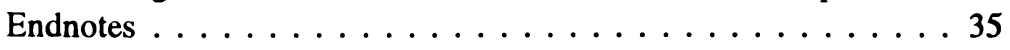

THREE Some Spurious Proofs for the Pure Ego . . . . . . . . 41 REM B. EDWARDS

1. The Argument from Unique Timeless Experiences . . . . . 45

2. The Argument from Meta-awareness . . . . . . . . . 46

3. The Argument from the Theory of Types . . . . . . . 47

4. The Argument from the Infinite Divisibility of Time . . . . 49

Endnotes . . . . . . . . . . . . . . . 50 
FOUR Formal Axiology and Its Critics $\ldots \ldots \ldots \ldots \ldots \ldots$ ROBERT S. HARTMAN

1. Critical Reception of the Theory . . . . . . . . . . 53

2. Reply to Charles Hartshorne, 1965, 1967 . . . . . . 56

3. Reply to Rem B. Edwards, 1968 . . . . . . . . . . . 61

4. Reply to Robert E. Carter, 1968, $1969 \ldots \ldots \ldots \ldots$. . . 65

5. Reply to G. R. Grice, $1968 \ldots \ldots \ldots$. . . . . . . . 69

6. Reply to Nicholas Rescher, 1969 . . . . . . . . . . . . . . 75

7. Reply to Robert W. Mueller, $1969 \ldots \ldots$. . . . . . 81

8. Reply to Gordon Welty, 1970 . . . . . . . . . . . . . . . 94

9. Reply to Pete Gunter, 1973 . . . . . . . . . . . . . . 106

10. Reply to George Kimball Plochmann, 1973 . . . . . . . . 109

11. Reply to Rem B. Edwards, 1973 . . . . . . . . . . . . 111

12. Reply to William Eckhardt and Robert S. Brumbaugh, 1973117

13. Conclusion: Theory and Practice . . . . . . . . 122

Endnotes . . . . . . . . . . . . . . . 125

PART TWO: CONTEMPORARY CRITICS

FIVE Ten Unanswered Questions . . . . . . . . . . . 145 REM B. EDWARDS

1. Measuring Personal Enrichment . . . . . . . . . . 146

2. The Duty to Reproduce, Contraception, and Mass Murder . 147

3. Duty and Supererogation . . . . . . . . . . . . . 147

4. Euthanasia . . . . . . . . . . . . . . 148

5. Generating Moral Rules . . . . . . . . . . . . . . 148

6. Complex Moral Rules with Qualifications and Exceptions . . 149

7. Assessing the Adequacy of Moral Rules . . . . . . . . 149

8. Human Rights, Conflicting Rights . . . . . . . . . 150

9. Moral Sanctions . . . . . . . . . . . . . . 150

10. Marginal Human Beings and Animals . . . . . . . . 151

Endnotes . . . . . . . . . . . . . . . . . 152 
SIX A Reply to "Ten Unanswered Questions" . . . . . . . . . . 153 FRANK G. FORREST

1. Measuring Personal Enrichment . . . . . . . . . . 154

2. The Duty to Reproduce, Contraception, and Mass Murder . 155

3. Duty and Supererogation . . . . . . . . . . . . . 157

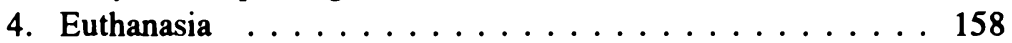

5. Generating Moral Rules . . . . . . . . . . . . 158

6. Complex Moral Rules with Qualifications and Exceptions . . 160

7. Assessing the Adequacy of Moral Rules . . . . . . . 162

8. Human Rights, Conflicting Rights . . . . . . . . . 165

9. Moral Sanctions . . . . . . . . . . . . . . . 166

10. Marginal Human Beings and Animals . . . . . . . . . 168

Endnotes . . . . . . . . . . . . . . . . 170

SEVEN A Quantum Wave Model of Value Theory . . . . . . 171 MARK A. MOORE

1. A Review of Certain Aspects of Quantum Logic . . . . . 175

A. Wave vs. Particle . . . . . . . . . . . . 175

B. The Wave Nature of the Electron . . . . . . . . 178

C. Wave Mechanics ... . . . . . . . . . . 179

D. Types of Waves . . . . . . . . . . . . . . . 180

2. The Relation of Quantum Theory to Value Theory ... . . 181

A. Wave Families: Types of Concepts . . . . . . . 181

B. Particles and Waves: Intensions and Extensions .... 182

C. Wave Interference and Value . . . . . . . . . 182

D. Heisenberg's Uncertainty Principle and Analytic Concepts . . . . . . . . . . . . 183

E. Conclusions . . . . . . . . . . . . . . . . 184

3. Quantum Wave Model for Value Combinations . . . . . . 184

A. Binary and Tertiary Value Combinations ....... 185

B. Extrinsic Value and Partial Fulfillment of Intensions . 198

C. Pascal's Triangle . . . . . . . . . . . . . 198

D. Ordinal Ranking of Values . . . . . . . . . . . 203

E. Comparing Ordinal Ranking of Values . . . . . . 203

F. Average Value for All Sets of Subsets . . . . . . . 206 


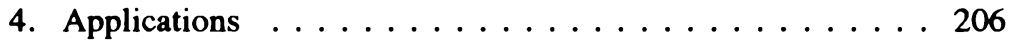

A. Compositions and Transpositions . . . . . . . 207

B. Better Than and Worse Than . . . . . . . . . . 209

C. Using Transpositions to Maintain or Create Value . . 210

5. Conclusion .................. 214

Endnotes . . . . . . . . . . . . . . . . 215

ABOUT THE CONTRIBUTORS $\ldots \ldots \ldots \ldots \ldots \ldots \ldots$

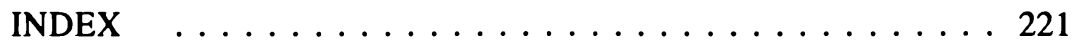




\section{EDITORIAL FOREWORD}

Robert S. Hartman responded in print only twice to his many critics. The first of these is the first essay to follow in this volume titled "Axiology as a Science." This article appeared originally in Philosophy of Science, 29:4, (1962), pp. 412-433, as a rejoinder to Hector Neri Castañeda's scathing review of La estructura del valor: fundamentos de la axiologia cientifica, published in Mexico in 1959, the Spanish version of The Structure of Value. The second, also included here, was the short "Reply to Eckhardt and Brumbaugh," in The Journal of Human Relations, 21:2 (Second Quarter 1973), pp. 220-225, a rejoinder to William Eckhardt's "The Place of Values in Human Relations" and Robert S. Brumbaugh's "Robert Hartman's Formal Axiology: An Extension" that appeared in the same issue of that journal. Hartman's reply to Eckhardt and Brumbaugh is incorporated into Hartman's "Formal Axiology and Its Critics" to follow in Part I. Several years ago, the incomplete manuscript of this article was called to my attention by Frank G. Forrest, who gave me a copy.

Although he did not publish most of his responses to his critics, Robert S. Hartman nevertheless was a prolific writer of such responses. Many of these rejoinders were in letters, copies of which now exist in the Hartman archives in the Special Collections Library of The University of Tennessee, Knoxville.

Hartman clearly intended to respond in print to his critics. Near the end of his life, he worked on a manuscript, unfinished unfortunately, titled "Formal Axiology and Its Critics," published in edited form here for the first time as Chapter Four of this volume. This extensively edited version of Hartman's responses to his critics is not a comprehensive rejoinder to all critics of formal axiology, but it covers most of them. An incredible and almost inexhaustible wealth of unpublished documents authored by Hartman in English, German, and Spanish exists in the archives at the Special Collections Library at The University of Tennessee. My sincere thanks to the librarians in that unit for their immense assistance and patience with my research efforts! I also want to thank other Hartman scholars like John W. Davis, Robert E. Carter, and Frank G. Forrest for providing me with essential research materials. I also express my deep appreciation to Frank G. Forrest and Mark A. Moore for the essays they contributed to this volume.

The responses and other essays to follow are prefaced in all instances by my introductory editorial comments in italics, which should help to place them in historical and philosophical perspective. I have completed, as best I could, Hartman's very incomplete footnotes. Interpretive footnotes of my 
own are placed within brackets [ ], as are important transitional words in the main text that I found it necessary to supply. In editing the letters, as integrated into the centerpiece article in Part I, "Formal Axiology and Its Critics," I changed all second person references to third person references, as Hartman himself would have done had he finished the article. I also consistently refer hereafter to myself in the third person. For persons unfamiliar with Hartman's revolutionary approach to understanding human values, I include the following "Introduction," which was originally published informally in January 1995 in Center $\odot$ View, the newsletter of The Center for Applied and Professional Ethics, here at the University of Tennessee.

Part I of the present volume consists of one critical article and two additional articles in which Hartman himself replied to his critics. All of the material in Part I was written before Hartman's death. Part II consists of articles presented in recent years at annual meetings of the Robert S. Hartman Institute for Formal and Applied Axiology. These articles show that the critique of formal axiology goes on, and that, in response to critical challenges, slow but steady progress is being made with the Hartmanean project of developing a formal science and calculus of values. I hope and believe that the foundations and the future promise of formal axiology will be much more secure with the publication of this book.

I want to thank my colleagues in the Department of Philosophy at the University of Tennessee, including especially George Brenkert our Department Head, for a faculty research leave during the spring semester of 1995 which made it possible for me to complete this book. I also thank Marie Horton, a departmental Secretary, for helping me so cheerfully with much of the scanning and typing. Finally, I thank the publishers and copyright owners listed in the following "Acknowledgments" for permission to use the lengthier material included in this book.

Rem B. Edwards The University of Tennessee May 1995 


\section{ACKNOWLEDGMENTS}

I wish to thank the following publishers and copyright owners for their kind permission to reprint articles, or quotes from, or summaries of sections of, the following.

1. British Journal for Philosophy of Science, David Papineau, Editor:

G. R. Grice, "Review of Robert S. Hartman, The Structure of Value," 19 (1969), pp. 179-180.

2. The R. S. Hartman Institute for Formal and Applied Axiology, Rem B. Edwards, Secretary, and Mrs. Rita Hartman:

For all the unpublished and previously published writings of Robert $\mathbf{S}$. Hartman included here.

3. The Journal of Human Relations, Ed Chamness, Office of University Communications, Central State University, Wilberforce, Ohio:

a. Robert S. Brumbaugh, "Formal Value Theory: Transfinite Ordinal Numbers and Relatively Trivial Practical Choices," 21:2 (Second Quarter 1973), pp. 211-215.

b. William Eckhardt, "The Place of Values in Human Relations," 21:2 (Second Quarter 1973), pp. 216-219.

c. Robert S. Hartman, "Reply to Eckhardt and Brumbaugh," 21:2 (Second Quarter 1973), pp. 220-225.

4. The Journal of Value Inquiry, Robert Ginsberg, Executive Editor: Summaries and quotes from the following are reprinted by permission of Kluwer Academic Publishers.

a. Robert W. Mueller, "The Axiology of Robert S. Hartman: A Critical Study," 3:1 (Spring 1969), pp. 19-29.

b. Gordon Welty, "Transfinite Cardinality and Hartman's Axiology," 4:4 (Winter 1970), pp. 293-301.

c. P. Y. A. Gunter, "Hartman: Three Criticisms," 7:2 (Summer 1973), pp. 136-140.

d. George Kimball Plochmann, "Robert S. Hartman on the Structure of Creativity: A Critique," 7:2 (Summer 1973), pp. 129-135.

e. Rem B. Edwards, "The Value of Man in the Hartman Value System," 7:2 (Summer 1973), pp. 141-147.

5. Prentice-Hall, Inc., Michelle Johnson, Permissions Editor:

Nicholas Rescher, Introduction to Value Theory, (1969), pp. 58-60. 
6. Philosophy of Science, Christine A. Kaye, Administrative Assistant: a. Hector Neri Castañeda, "Review of Robert S. Hartman, La estructura del valor: fundamentos de la axiologia cientifica," 28 (1961), pp. 89-93.

b. Robert S. Hartman, “Axiology as a Science," 29:4, (1962), pp. 412-433.

7. Southern Illinois University Press, Walter Kent, Editor:

Robert S. Hartman, The Structure of Value: Foundations of Scientific Axiology, 1967. 